\title{
Identify the Values of Ancestor Worship Belief in the Spiritual Life of Vietnamese People
}

\author{
Vu Hong Van ${ }^{1}$, Nguyen Trong Long ${ }^{2}$ \\ ${ }^{1}$ Department of Basic Science, University of Transport and Communications, Hanoi, Vietnam \\ ${ }^{2}$ Department of Political Theory, Ho Chi Minh University of Natural Resources and Environment, Ho Chi Minh City, Vietnam
}

Email address:

vhvan@utc2.edu.vn (V. H. Van), ntlong@hcmunre.edu.vn (N. T. long)

\section{To cite this article:}

Vu Hong Van, Nguyen Trong Long. Identify the Values of Ancestor Worship Belief in the Spiritual Life of Vietnamese People. International Journal of Philosophy. Vol. 7, No. 4, 2019, pp. 160-166. doi: 10.11648/j.ijp.20190704.14

Received: November 17, 2019; Accepted: December 2, 2019; Published: December 9, 2019

\begin{abstract}
Ancestor worship has an important place in family and society of Vietnam. This is a way of expressing gratitude and tribute to the deceased. According to the concept of Vietnamese people, the deceased often engage in the present life, they guide, direct, protect us, blessing us, etc. Up to now, the phenomenon of ancestor worship still exists in many nations and people. However, its position and role in the spiritual life of Vietnamese people in each place is different. In some countries, ancestor worship has a faint role in the spiritual life of the community, especially the nations and peoples that have worship a single religion. But in many countries, there are concepts of polytheism, pantheism, ancestor worship plays an important role in the spiritual life of each individual, community and society. In Vietnam, most people worship ancestors, including followers of some religions. People perceive this belief both as a traditional custom and as a human morality as well as a form of spiritual activity. This study provides a discussion of: the origin and nature of ancestor worship belief; object of ancestor worship; the formation of Vietnamese ancestor worship belief; ancestor worship rituals and values of ancestor worship belief in the spiritual life of Vietnamese people.
\end{abstract}

Keywords: Belief, Ancestor Worship, Spiritual Life, Vietnamese People

\section{Introduction}

In the forms of folk beliefs, ancestor worship is a kind of tradition belief of the Vietnamese people. Being Vietnamese, "everyone worshiped ancestors, everyone worshiped grandparents" [2, 3]. Ancestor worship has become a traditional custom, has a very special position in the spiritual life of the Vietnamese people, and is one of the elements that make up the cultural identity of Vietnam. The beliefs of ancestor worship are very simple: believing that their ancestors are sacred, ancestors go into eternity but still live next to their descendants, they bless their children when they encounter troubles and difficulties; when their children get lucky, ancestors so happy, encourage them when they have good things, and also rebuke them when doing bad things, etc.

For Vietnamese people, this belief almost becomes a system of values that cannot be changed; no family does not have an ancestor altar in the house. In poor families, the altar is simple, with few objects to display (Figure 1), and in rich family, the altar is made very large, has many objects and is decorated very sophisticatedly (Figure 2). Our people have the phrase "parents raise their children by the sky, by the sea", which is not only the spiritual meaning of parents giving birth to raising children, but also from a patriarchal agricultural economy. From the concept of spiritual sentiment, for any Vietnamese, they respect their parents when they live and worship when they die. Just like that, from generation to generation, he towards his father, father to children, successive from generation to generation, into a social life, an ancestor worship belief. Ancestor worship was rooted in the internal of the nation [3], after which foreign religions (Confucianism [21], Buddhism [17], Taoism [10]) introduced, especially Confucianism that made ancestor worship beliefs put into practice, effectively serving the patriarchal feudal regime.

It can be said: "ancestor worship belief is the most common belief of Vietnamese people. It stems from the belief that the souls of the dead still exist in our world and 
affect the lives of our descendants" [18]. From the real life, the worship and gratitude for the deceased gave birth to the worship of ancestors, widespread in the Vietnamese people. Ancestor worship activities usually take place on the anniversary of death, holidays, Lunar New Year, etc, to commemorate the deceased, express admiration, respect, etc and wish to "bless" for all good things. Vietnamese people take the gratitude as a moral foundation, and descendants must be grateful to those who were born them. The death anniversary of parents, grandparents, etc is the day to meet the children, grandchildren, descendants gather together enough to create a strong relationship for family relations. In fact, whether or not there is a soul is unknown, but one thing is for sure, that the descendants must be grateful to their ancestors.

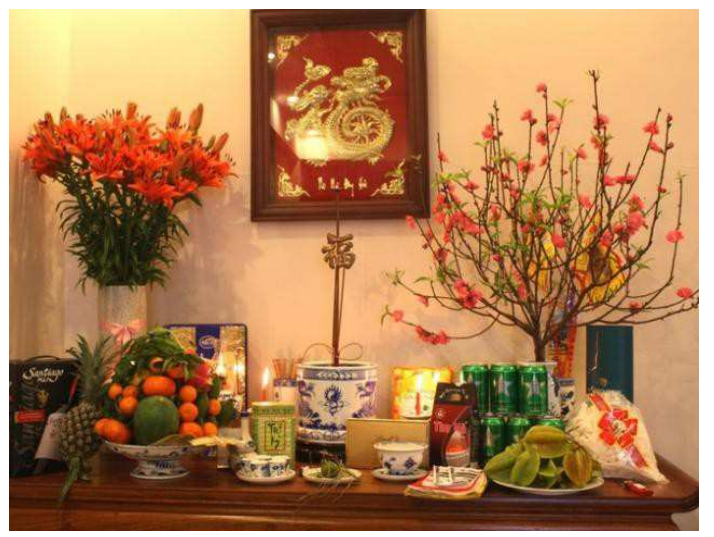

Figure 1. Altar in poor family.

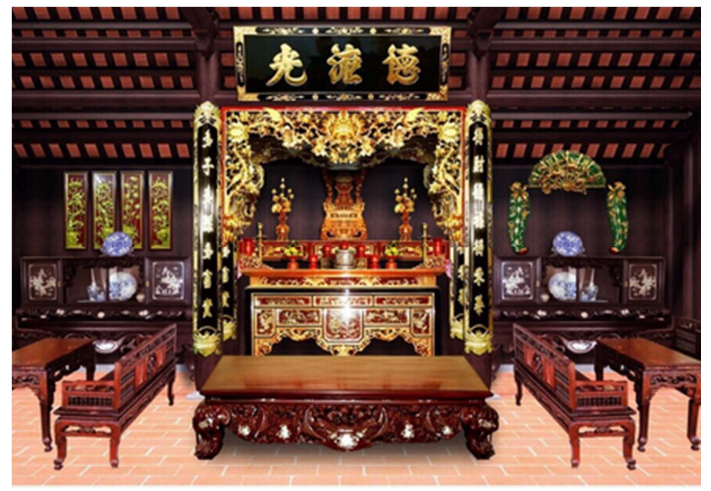

Figure 2. Altar in rich family.

\section{The Concept of Ancestors}

In the Vietnamese perspective, ancestors are a term used to refer to people who have the same bloodline but who have died as parent, grandparents, great - grandparents, greatgreat-grandparents, etc., who have born and nurtured, have a great impact on the material and spiritual life of the generations of the people who is living.

According to research by many ethnographers [16, 22], the ancestors in the original society originated as the ancestral ancestors of the tribes. The Totemism ancestor of the matriarchal period is things in nature, closely related to humans and when deified and sacred, it is considered the totem of the clans and tribe. During the patriarchal mode period, the ancestors were the heads of the gens and tribes such as chiefs, military leaders, etc, full of authority. The ancestors in society had a class division that was more fully shown. They were often the holders of the head of the family, the clan leader, had the right to inherit property and recognized by law and society. [8, 16, 21, 22].

In the development process of history, the concept of ancestors has also changed and developed. It is no longer confined to the family, clan, etc., but has expanded to the scope of the community and society. The formation and development of nations and peoples is often associated with the names of people who have created and maintained the life of the community. They were heroes and celebrities who, while living, are revered, respected, lost, remembered, worshiped in religious spaces. In Vietnam, they were the ancestors of the craft, the village's tutelary gods, national heroes, cultural celebrities, etc.

\section{The Object of Ancestor Worship}

\subsection{Worship of Ancestors in Family}

Worship is an element of the sense of ancestors, a feeling of gratitude, remembrance, towards the origin, the past. Ancestor worship is an expression of respect, gratitude, and remembrance of the ancestors, and it is also an expression of belief in the protection and assistance of ancestors. The basis of the formation of ancestral consciousness is the belief in the soul of an ancestor alive, able to protect and bless the offspring. The symbol of ancestors is the image of talented, meritorious and virtuous people. On the ancestor altar, there are usually tablets, statues, photos are placed in an elaborate and solemn setting.

The offering is a ritualistic element, the practice of a series of activity (praying, kneeling, and bowing) of the patriarch or eldest son (Figure 3). It is an activity in the form of rituals and is regulated by the conception, customs and practices of each community and ethnic group. Worship and offering are two factors that interact and create a separate form- ancestral worship. The worship is the content, while the offering activity is the expression of the content of worship. The sense of worship, devotion, gratitude, tribute, hope for the support of the ancestor. If there is not "worship" but only "offering", ancestor worship without "spirit", without the inner attractiveness, becomes bland and therefore cannot be ancestor worship. The "worship" is only a form of expression, but it reveres, sacred, mysterious, fanciful and attractive. It is the adhesive, creating colors that satisfy the beliefs of the worshiping subject.

"According to ancient Vietnamese people, death is not the end. A person is dead but his or her soul still remains and usually "frequents" the family. The body dissolves, but the soul is immortal" [2, 3]. Family members (grandfathers, grandmothers, fathers, mothers, brothers, sisters, etc.) who are dead still have needs and desires like the living. "People also believe that life in the underworld is the same as life in 
on earth. The dead also need such things as when they were alive. In other words, the dead aslo need to eat, drink, spend money and live in houses like the living" [2].

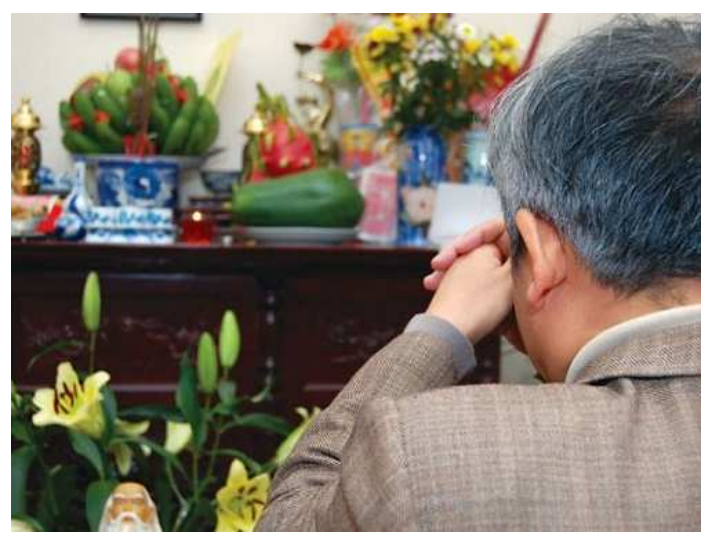

Figure 3. The eldest son or patriarch worship the ancestors.

Right after a person's death (the soul has left his or her body), to lighten the steps of the soul when leaving the body, the living people (relatives in the family) will have to light candles, burn paper money or gold to pay the soul's travel expenses to the underworld and make offerings of food and drinks to reduce the hunger and thirst of the soul.

People burn things made of paper exactly like the things living people need like furniture, horses, servants, etc. to the souls; rich people even burn paper bicycles, motorbikes, cars and sometimes planes. In the current society, people also burn mobiles and tablets to the souls. The sacred duty of a filial son is to meet all the needs of his deceased ancestors. In Vietnam, the person who performs the above rituals is usually the eldest son (or religious grandson) of the family. In addition, children and grandchildren can also set up their own altars at home. However, on important days such as death anniversary, grave transfer, etc., they must gather at the eldest son or the patriarch's home.

It can be said that "the custom of worshiping ancestors is the most popular belief of Vietnamese people. It comes from the conception that the souls of the dead still exist in this world and affect their descendants' lives" [18]. The worship of ancestors often takes place on the death anniversary, holidays and Lunar New Year to commemorate the dead, show admiration and respect and pray for all good things to come. Vietnamese people take gratitude as their moral foundation, that is, descendants must be grateful to those who gave birth to them. The death anniversary of ancestors reminds descendants of the date when they died and creates the basis for family relations. Nobody knows whether there are souls or not, but one certain thing is that descendants must be grateful to their ancestors.

Vietnamese people make offerings to their ancestors' souls on their date of death (death anniversary), which is usually calculated according to the lunar calendar. Descendants believe that it was the date when their ancestors' souls went to the afterworld. Not only on death anniversary, the worship of ancestors is also carried out regularly on the first and the fifteenth of lunar months, and holidays. When there are important events in the house such as getting married, giving birth, building new houses, going away for work, taking examinations, etc., Vietnamese people also make offerings to their ancestor souls to report and pray for good luck or to show gratitude when their work is successful.

The nature of the worship of ancestors' souls of Vietnamese people originates from the belief that the living and the dead have a close relationship with each other. Descendants pray for their ancestors and ancestors protect and guide their descendants. So, the worship is considered a connection between the living and the dead.

Beliefs in the death suggest that "tử tuất quy thổ, cốt nhục tê ư, hạ âm vi giả thổ, kỳ phí phát dương ư thượng vi chiêu minh" (the dead people were buried in the ground, their bodies were decomposed, melted, buried in the ground were only fake, the soul was allowed to fly to the sky). This means that people who die will surely return to earth; their flesh and bones dissolve into the ground and their souls fly high in the air. "The worship of ancestors is a belief since people consider their ancestors' souls as tutelary deities that protect them in their whole lives" [5].

\subsection{Ancestor Worship at the Village and Commune Level}

In the villages and communes, Vietnamese people worshiping "Thanh Hoang Lang" (Village's Tutelary God). The Village's Tutelary God is a common noun to refer to a god worshiped in a Vietnamese village. Like Tao Cong (Kitchen God), Tho Cong (Earth God) and Than Tai (Rich God), the Vilage's Tutelary God ruled and decided the blessing of a village and was often worshiped in the village communal house. Therefore, almost every village or street (where the city is) establishes a communal house (or temple, shrine) to worship the Village's Tutelary God of the village or guild. The Village's Tutelary God was a man who with meritorious services to the people and the country. Thus, "The Village's Tutelary God is the most sacred symbol of the whole village, in every village, throughout the old villages" [6].

Each of the Village's Tutelary God had a divine and divine genius associated with the characteristics, natural conditions and historical circumstances of the village. However, there were cases where many villages worship a Village's Tutelary god, such as Tan Vien God, worshiped by many villages in the former Ha Tay province, although the gods of this god in each locality are different: in the Do village, Tan Vien God was worshiped for his gratitude for teaching people to do farming and singing; in Shandong, he was again worshiped by the merit of teaching people to make grass sickles, reaping rice, who taught people to weave baskets from rattan and bamboo to make tools to carry grass, rice, etc.

The Village's Tutelary Gods were often worshiped at communal houses and shrines (Figure 4), but sometimes there were a place to worship the village Tutelary God at the temple according to the motif of "Before the God, after Buddha". With the viewpoint of " three religious prairies" (three religions of the same origin), many monks and nuns were enlightened as: Tu Dao Hanh meditation teacher (Thay 
pagoda - Ha Tay old province - Today is Hanoi) was conferred as the Holy Father, to be called the Tu Holy; Khong Lo meditation monk (Keo pagoda - Thai Binh province) was conferred the title of Holy Patriarch, to be called Khong Lo Holy; Hue Tzu meditation monk (Co Tung pagoda - Nam Dinh province), was conferred Duc Bao Trung Hung - Linh adored the spirit, calling him the Tu Holy...

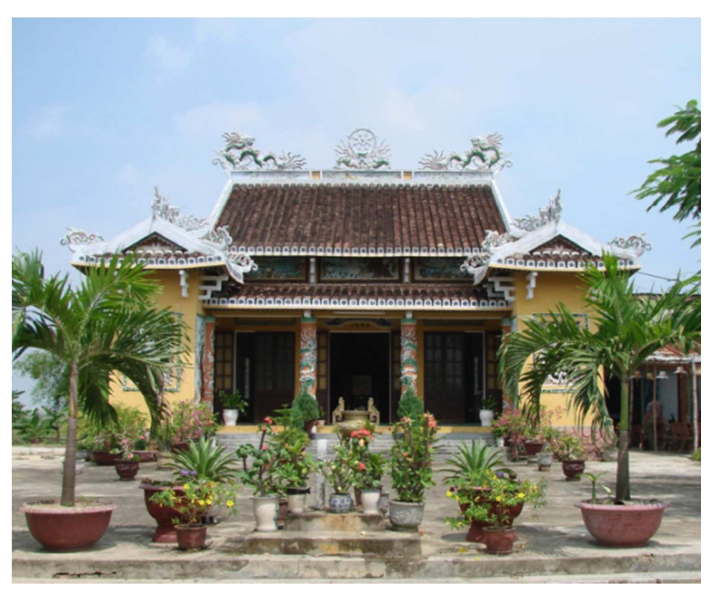

Figure 4. A village temple in the central region of Vietnam.

“Gods. Each village served a Village's Tutelary God, sometimes a village worshiped two, three Village's Tutelary Gods, a village worshiped five and seven Village's Tutelary Gods who known as the Blessed spirit. The spirit has been divided into three categories: Upper gods; Middle gods; Inferior gods" [18].

The Upper gods: including gods with great merits to the people, with the country, were ordained by the king and established temples such as Tran Hung Dao, Hai Ba Trung, Ly Thuong Kiet, Pham Ngu Lao,... and the angels were widely circulated in humanity about their merits to help people and help the country such as Tan Vien Son Than (Tan Vien God), Thanh Giong, Lieu Hanh Princess, Chu Dong Tu, etc. All these gods had their merit and merit the king ordained as a senior god [5].

The Middle gods: including gods or local officials who openly fill, set up hamlets, have gratitude to the people, sometimes gods that the villagers have long worshiped, whose surname was unknown, or there were the bishop who did not know their name, or the gods with a bit of aura, until the king of the island came to fulfill the dynasty, then the court made Middle god.

The Inferior gods: including gods worshiped by the villagers, although they do not know the divine powers, but also belong to the divine authority. The feudal court followed the villagers and ordained a lower class.

In addition to the above three gods, many villages worship strange gods such as the beggar god in Thu Lan village (Ha Nam province to day); god of theft in the village of Phu Khe - Thai Binh province; god of feces in Co Nhue village (Hanoi capital today); Child god, Ta Dam god, etc. According to the explanation of the folk, these gods, apart from their unusual abilities, were worshiped by the dead at sacred hours. At first due to fear, the villagers worshiped after a long time, they were worshiped to help the villagers dispel risks, to sponsor the existence and development of the village community [5].

\subsection{Ancestor Worship at the National Level (Worshiping Hung Vuong)}

For thousands of years, the people of Vietnam have had a sincere and sacred belief towards the origin, the Hung Kings, who had contributed to the first Van Lang and Au Lac State, as well as taught the plowing people, paddy fields, transplanting rice, giving spiritual energy to land, houses, crops and livestock to thrive, good harvests. For Vietnamese, it is not only a sacred belief towards the origin, but also a spirit of building and defending the country, preserved and handed down for generations.

According to legend, Hung Vuong (Hung Kings) was the son of Lac Long Quan's father - derived from dragons and $\mathrm{Au}$ Co's mother - derived from Fairy, who had made a contribution to the ancient state of Van Lang, in today's Phu Tho land. For the community of villages around Hung temple, Hung Vuong is also a god associated with agriculture. The worship of Hung Vuong was carried out by Later Le and Tay Son dynasties (1788-1802). The Commemoration Feast of Hung Vuong is held on the 10th day of the 3rd lunar year in Hung temple, Nghia Linh commune, Doan Hung district, Phu Tho province today. Each year on the anniversary of the death anniversary, thousands of people flock to this place to burn incense to commemorate the Hung Kings (Figure 5).

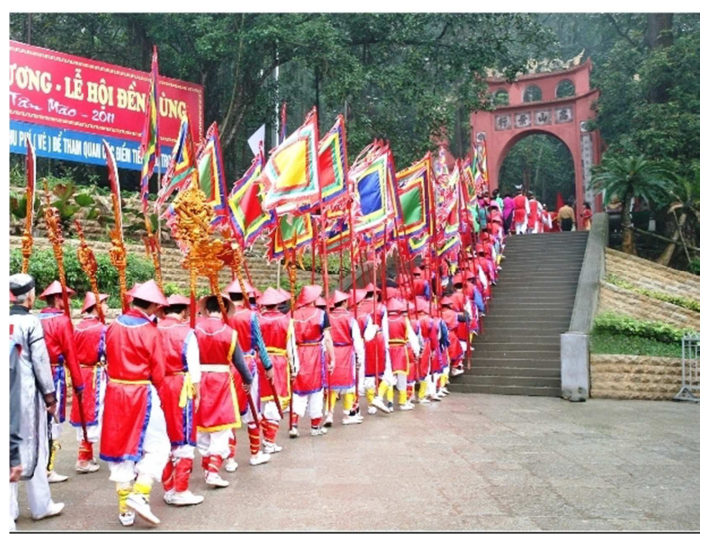

Figure 5. Hung Kings Anniversary holiday (Source: Ngoc Long).

According to many researchers, the custom of worshiping Hung Vuong was confirmed early in the book Linh Nam Chich Quai by Vu Quynh in Le Thanh Tong period. At that time, with the spirit of national independence and affirming Dai Viet's national culture after the victory against the Ming army, the mythical symbols of national origin were enhanced, and the worship of Hung Kings continued, linking previous myths in Linh Nam land, had deeply affirmed the nation's independence. This was also maintained throughout feudal history.

According to the researchers [3, 5, 9, 18], in 1917 during the reign of Khai Dinh, it was celebrated on March 10 before 
the ancient custom a day, and confirmed the death anniversary of Hung Vuong as a national level. And in February 1946, after we gained independence and built the Democratic Republic of Vietnam for a year and a half, President Ho Chi Minh signed Decree No. 22 for civil servants to leave on March 10 Lunar calendar each year to celebrate the Hung Kings Anniversary with the tradition of drinking water and remembering the source.

The Commemoration Feast is solemnly performed with special rituals handed down from generations to generations. On the occasion of the death anniversary, people in the villages worshiped Hung Vuong (Hung Kings) in Hung Temple area on Nghia Linh mountain, dressed in festive costumes, colorful flags and colors, held palanquin and made offerings. The most beautiful palanquin and the best offering, together with gongs, drums, rituals, etc were chosen to pick up the Hung temple to worship and pray for the people's national security. Offering offerings include Chung cake, Giay cake, etc, (pork, beef, goat) and fragrant flowers and sweet fruits. In addition, young men in the villages also take part in the procession, hold flags, fans, and parasols in the procession. The Commemoration Feast also features folk performing arts such as oval singing, teasing, and other folk games that attract not only villagers but also cross-border visitors.

\section{The Role of Ancestor Worship in the Spiritual Life of Vietnamese People}

\subsection{Conscious of the Roots of the Nation}

Researchers in Vietnam all suppose that the era of the Hung Kings and the subsequent An Duong Vuong (between the second millennium and the first millennium BC) $[6,8$, $13,24]$, whose material base is civilized Dong Son was the period of formation of the ancient Vietnamese ethnic group, the foundations of traditional culture and the formation of the first nation: Van Lang - Au Lac. The community of people in the history of prehistoric history has required awareness of the natural world, society and self-awareness, thereby initially building for themselves symbols and values, but increasingly with the development of feudal society, the ruling class represented the existing social regime, conscious of developing and consolidating those symbols and values of social consciousness.

That early and inclusive consciousness is that of the Vietnamese people. Vietnamese people, whether old or young, boys or girls all remember in their hearts are children of Dragon, nephew of Tien (Fairy), same red blood, yellow skin, born from the "Mot boc tram trung" (compatriot), the same homeland. Therefore, in any situation, in peace or in a country in danger of invaders, all gather to survive, unite to fight, create strength that has been challenged for thousands of years, becoming the power to overcome all enemies.

Due to the characteristics of the geographical position, one of the factors that formed the national national consciousness at the earliest was the anti-foreign aggression. Vietnam, since the formation of the ancient state so far, most of the time, about twelve centuries was against foreign aggression. Right from the time of the Hung Kings, our fathers have fostered a sense of anti-foreign aggression and cultivated the love of the country. Rarely has a nation since the beginning of history created the legend of Thanh Giong, a boy who was only three years old said the first sentence to ask the king to fight with the invading enemies.

The history from the founding of the country up to now shows that: The generations of our ancestors have never been ambiguous about national consciousness. The will to protect the territorial integrity, to unite the whole country, to build a strong nation covering all eras and institutions. That consciousness flows in the blood of every generation of Vietnamese people, whether at home or abroad. That explains why Vietnamese people, despite being away from home for a long time, are still facing the Fatherland, and why Vietnamese people in the south and abroad still worship King Hung and remember the anniversary of the death anniversary. The strength of the nation's roots is there. Cultural researcher, Nguyen Chi Ben once said:

"In the social aspect, the value of Hung Vuong (Hung Kings) worship belief is the expression of community cohesion, the tradition of national solidarity. The worship of Hung Vuong can be considered as a red thread connecting the past with the present, which is a spiritual foundation for generations of Vietnamese people".

\subsection{Educate People with Filial Piety, Gratitude}

From time immemorial, filial piety has been evaluated through gratitude and care for parents and worship of their ancestors. This is an important virtue, the core of human morality. The wise men in the world once discussed how to establish a good society using the principle of filial piety. Filial piety has played a central role in the moral philosophy of Confucianism and throughout the spiritual life of Asians from past to present. Up to this modern age, filial piety is still considered an important human quality.

The history of cultural and ideological development of humankind has shown that filial piety means being kind to your parents; take care of his parents; have good behaviors not only for parents but also for outsiders to bring good reputation to parents and ancestors; perform well the tasks and work to ensure material support for parents as well as for ancestor worship. Show love, respect, and politeness; promote brotherhood among brothers; advising parents wisely, including keeping them from unethical behavior; expressing mourning, expressing sadness when his parents died and performing funeral ceremonies seriously and solemnly; thoughtful worship after his parents passed away.

Since ancient times, Asians have had a filial tradition. The annual $\mathrm{Vu}$ Lan Festival (on the 15th day of the seventh lunar month) is a holiday to honor the ancestors of their parents and grandparents, including grandparents and parents for many lifetimes. In Vietnam, Vu Lan Festival is considered to be an important holiday for parents, is the day towards the ancestors, the family and the lineages. Vu Lan Festival has a 
sacred meaning in expressing gratitude to ancestors, parents and grandparents, in practicing filial piety according to the Buddha's teachings through practical and valuable practical works for relatives of yourself. Through the Vu Lan Festival, the children themselves have the idea of committing to live well, in accordance with traditional morality and in accordance with the Buddha's teachings in order to deserve the thanks of their parents, worthy of a true filial son.

\subsection{Strengthening the Spirit of National Solidarity, Love and Mutual Assistance between People and People}

As discussed above, in Vietnam, every family has an ancestor altar placed in the most solemn place, in the aspect of a village, to worship a village tutelary god, in the aspect of the nation that is to worship the Ancestor King of a country Hung Vuong. Therefore, worshiping the Hung Kings and the heroes who have meritorious services to the people and the country is to show filial piety, gratitude and respect for the merits of their predecessors, which is the basis for forming kindness, community.

The process of awareness of ancestors, Hung kings and people with meritorious services to the people and the country is the beginning of kindness in every human being and in social community. This reminds each person to act according to a certain standard and to strengthen the belief in the witness, protection and expectation of the ancestors of the Hung Kings.

The merit of Hung kings is handed down from generation to generation, worshiped and grateful by the community. The symbol of the hero who founded the country is therefore the source of the patriotism of the Vietnamese nation. The consciousness of the Hung Kings is also the consciousness of the origin of the nation and the country, thereby forming the spirit of national resilience and the sense of independence and autonomy.

The Vietnamese people have experienced the ups and downs of many wars, but patriotism and the sense of independence and autonomy have never been turned off by generations of Vietnamese people, creating a distinctive value in the system. Traditional ethical values of Vietnamese people. Building and defending the country was the theme throughout the history of the nation, and to this day, the Vietnamese generations have continued the career of the Hung Kings in the new era.

\section{Conclusion}

It can be said that ancestral worship reminds each of us, wherever we are, far from our homeland, but always worship and engrave our roots. Thereby educating each person is always responsible for the homeland, preserving and promoting the good values that our ancestors have cultivated. This custom is like a bond between the living and the dead, those on earth and those in the spiritual world. This expressed the concept of human life of the Vietnamese people "death as birth, death as existence".

According to the Vietnamese perspective, death is not the end, ancestors are always watching and blessing us in life. Thanks to this form of belief, Vietnamese people express gratitude and devotion, filial piety to ancestors and grandparents who have given birth to nurture us. We always believe that, after losing, ancestors never disappear but always stand side by side with our descendants and we should fulfill the filial duty of a child. These values are always summarized and taught to our generations through the most meaningful verses of "Eat the fruit remember the tree growers" or "The tree have root, leaves and branches was develop. Water is sourced, the sea is wide, and the river is deep".

In every Vietnamese family, ancestor worship transmits profound morality "drink water to remember the source" has become a beauty in Vietnamese culture. Through this, every human being understands the value of "filial piety" in life in relation to family members. Father's hard work like a mountain, the motherhood of his mother is as vast as the vast sky. So we must always be filial and grateful to our parents while still alive and always remain sincere and show respect and mercy when their parents return the eternal world. The most valuable value hidden in Vietnamese ancestor worship is the teaching of filial piety. Thus, ancestor worship is not only a traditional beauty of national culture but it is also an invaluable moral lesson in each person's subconscious. It teaches people about filial piety, filial virtue and towards the origin of ancestors.

\section{References}

[1] Anh, D. D. (1998). Vietnamese Cultural and Historical Draft. Dong Thap: Đong Thap Universal.

[2] Anh, T. (2005). The custom of worshiping in families and public places in Vietnam. Hanoi: Thanhnien.

[3] Binh, P. K. (2005). Vietnamese custom. Hanoi: Culture information.

[4] Chu, P. H. (1992). Least-year charter schedule. Hanoi: Social Science.

[5] Duy, N. D. (2002). Spiritual culture. Hanoi: Culture information.

[6] Dai Viet Su Ky Toan Thu. (2004). Volume 1. Hanoi: Social Science.

[7] Dai Viet Su Ky Toan Thu. (2004). Volume 2. Hanoi: Social Science.

[8] Giau, T. V. (1973). The development of thought in Vietnam from the nineteenth century to the August revolution. Hanoi: Social Siences.

[9] Giau, T. V. (1983). Traditional spiritual values of the Vietnamese nation. Vietnam: Ho Chi Minh.

[10] Hinh, N. D. (2007). Vietnamese Spirituality. Hanoi: Bach Khoa dictionary.

[11] Huong, N. X. (2009). Beliefs of coastal residents in Quang Nam - Da Nang. Hanoi: Encyclopedia \& Cultural Institute. 
[12] Huy, C. X. (1995). The Oriental ideology with suggestion of reference viewpoints. Edited by Chi. N. H. Hanoi: Literature.

[13] Huyen, N. V. (1995). Contributing to the study of Vietnamese culture, Volume 1. Hanoi: Social Sciences.

[14] Huu, T. D. (1996). Come modern from tradition. Hanoi: Culture.

[15] Institute of History. (2007). Vietnamese History, vol 3. Hanoi: Social Sciences

[16] Karl Marx \& Friedrich Engels. (1995, trants). Complete episode. Episode 21. Hanoi: National Political.

[17] Lang, N. (1974). Vietnam Buddhist History. Saigon: La Boi.

[18] Ngoc, P. (2002). Vietnamese cultural identity. Hanoi: Literature.

[19] Roszko, Edyta. (2012). "From Spiritual Homes to National
Shrines: Religious Traditions and Nation-Building in Vietnam" (PDF), East Asia, 29: 25-41, CiteSeerX 10.1.1.467.6835, doi: 10.1007/s12140-011-9156-x.

[20] San, N. M. (1998). Access to Vietnamese folk beliefs. Hanoi: Ethnic Culture.

[21] Thu, N. T. (1997). The influence of ideologies and religions on Vietnamese people today. Hanoi: National politics.

[22] Tylor, E. B. (2000). Original culture. Hanoi: Art and Culture.

[23] Vuong, T. Q., \&Tan, H. V. (1960). History of Vietnamese feudalism, vol 1. Hanoi: Education.

[24] Vuong, T. Q., \& Tan, H. V. (1960). History of Vietnamese feudalism, vol 2. Hanoi: Education.

[25] Y, N. N., \& Huy, C. (2011). Cultural dictionary, traditional Vietnamese customs. Hanoi: Vietnam Education. 